\title{
An Estimation of Fish Biomass and Attached Organisms beneath Oyster Rafts in Hiroshima Bay, Japan
}

\author{
Wahyudin Wahyudin ${ }^{1 *}$ and Tamiji Yamamoto $^{2}$ \\ ${ }^{1}$ Marine and Fisheries Faculty, Raja Ali Haji Maritime University, Jl. Politeknik Senggarang- Tanjungpinang, Riau Islands \\ Province 29100, Indonesia \\ ${ }^{2}$ Graduate School of Biosphere Sciences, Hiroshima University, Higashi-Hiroshima 739-8628, Japan
}

\begin{abstract}
Hiroshima Bays is top production approximately $60 \%$ of oyster production in Japan. For cultivate of oyster, fishermen use hanging rafts. A thousand of raft is hanging during 2-3 years in the bay. Largescale oyster culture may change the ecosystem structure and material cycles in the bay through the filtration of particulate matter by oysters and other associated animals. This study described the community structure of marine organisme in terms of fishes surrounding and animal attached on oyster rafts. Field observation was carried out from 2016 to 2019 at oyster farming in Hiroshima Bay. Oyster production and provisioning for the fish habitat were also evaluated by placing underwater video cameras beneath oyster culture rafts. The result showed that black seabream was high biomass and oyster it shelf was bigger bioyster for animal attached on oyster raft. The number of individual, mussel is most abundance of animal attach on oyster raft with ratio 9:1 than number of oyster. Maintaining oyster culture is important not only for maintaining oyster production, but also for maintaining fish production by enhancing material cycles through the paths in the food chains of Hiroshima Bay under oligotrophic conditions.
\end{abstract}

\section{Introduction}

Aside from being an important food source to humans, oysters have a variety of functions in coastal and estuarine ecosystems. The function as natural filters and make water clearer by filtering out suspended particulate matter-both living (phytoplankton) and dead (detritus) [1]. In estuaries and coastal areas, where oysters are intensively cultured, they may control phytoplankton dynamics by grazing activity [2]. Thus, the impact of oyster harvesting activities on the removal of particles containing nitrogen and phosphorus from the water column-making the water clearer [3] - is worth evaluating. [4] Estimated that bivalves cultivated worldwide remove 49,000 tons of nitrogen and 6,000 tons of phosphorus, with a potential of $\$ 1.2$ million in 2015, globally.

In Japan, approximately $60 \%$ of the total national oyster production comes from Hiroshima Bay [5]. [6] reported that approximately 12,000 oyster rafts are floating in Hiroshima Bay. Besides the obvious economic benefits, the existence of oyster cultures provides numerous important services to the ecosystem. For example, oyster cultures serve as habitats for invertebrates attached to the rafts $[7,8]$. Cultured oysters also provide feeding and/or nursery grounds for several fish species [9]. Through their filtration activities, oysters and other attached suspension feeders alleviate turbidity in estuaries [10]. They remove suspended particles regardless of their nature (e.g., inorganic particles, phytoplankton, and detrital particles), thereby reducing turbidity and improving water transparency $[1,11]$.
Although economic valuations of ecosystem services provided by oyster reefs have been widely reported, an estimation of the value provided by hanging oyster rafts has not yet been quantified. This study aimed to evaluate the ecosystem services provided by the oyster cultures in term of fish biomass and attached organisms estimation in Hiroshima Bay

\section{Methods}

Field observations were carried out at five stations located in the northern part of Hiroshima Bay (nHB) from June to August 2016 (Fig. 1). In Hiroshima Bay, oyster culture was operated traditionally with $8 \mathrm{~m}$ wide $\times 16 \mathrm{~m}$ long rafts [12]. Fishers collect the oyster larvae from nature using a scallop shell collector. Forty scallop shells are hung on one $10 \mathrm{~m}$ long wire line, and, on average, 688 wires are set on one raft [6].

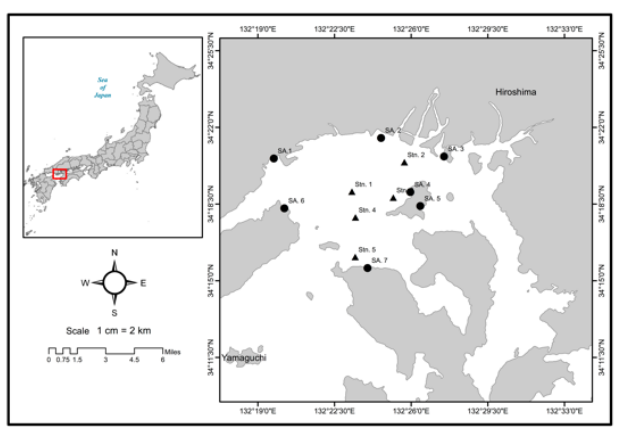

Fig. 1. Map showing the northern part of Hiroshima Bay and the location of the sampling stations. $\boldsymbol{\Lambda}$, oyster raft stations (Stn); $\bullet$, shoreline stations (SA)

*Corresponding author: wahyudinps@umrah.ac.id 
Fish under oyster rafts were observed using three GoPro cameras (GoPro, Inc., San Mateo, CA, USA) placed under the raft at $2.5 \mathrm{~m}$ depth. Camera observations were conducted during the daytime for $1 \mathrm{~h}$ at three different oyster rafts, and were carried out three times from July to August 2020 (July 6, August 3, and August 17). To scale the area observed, four $5 \mathrm{~m}$ long white ropes weighted with lead were suspended around the raft (front, behind, and left and right sides) at a 2.5 $m$ distance from the cameras. Thus, the total area for fish observation was $125 \mathrm{~m}^{3}$ for each video recording. The number of fishes that appeared in the scenes per minute were identified and counted.

Eleven fish species were observed, of which five dominant species (higher than $5 \%$ of the total species abundance) were selected for the evaluation of the biomass $\left(\mathrm{g} \mathrm{m}^{-3}\right)$. The density of each mobile fish species, $D$ (ind. $\mathrm{m}^{-3}$ ), was estimated using Eq. (1):

$$
D=\frac{\sum_{i=1}^{P} n i}{\mathrm{r}}
$$

Where $n i$ is the number of fishes seen in one scene (ind.) and $r$ is the area observed $\left(\mathrm{m}^{3}\right)$.

Based on their size and the existing literature (www.fishbase.org), each fish was classified into two categories: juvenile and adult. The weight of fish, $W$ (g $\mathrm{m}^{-3}$ ), was estimated using the following equation [13]:

$$
W=a L^{b}
$$

Where $a$ (intercept) and $b$ (slope) were cited from the literature summarized in Table 1.

Filter feeders were collected at three oyster raft stations. At the shoreline stations, the samples were collected on different days from June to August 2016. One oyster cluster each was collected from 1 and $4 \mathrm{~m}$ depths every month from June to August. All animal samples were kept in a cool box and brought to the laboratory, where they were identified, counted, and weighed

\section{Results}

As shown in Figure 2, of all the organisms present in the oyster rafts, the oysters had the highest biomass $(13.7 \mathrm{~kg}$ fresh weight $[\mathrm{FW}] \mathrm{m}^{-3}$ ) in $\mathrm{nHB}$. The black seabream (Achanthopagrus schelgelii) was the most abundant fish associated with oyster rafts; they showed the highest biomass $\left(63.2 \mathrm{~g} \mathrm{~m}^{-3}\right)$, probably due to their common appearance and larger size. Our video camera recordings showed that five commercial fish species (black seabream, black scraper, pufferfish, Japanese seabass, and black rockfish) were the dominant species under the nHB oyster rafts.
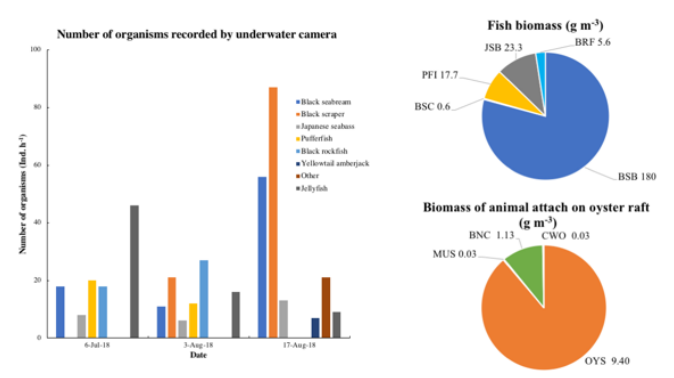

Fig. 2. Number of organisms recorded by underwater camera, fish biomass, and biomass of animal attach on oyster rafts

\section{Discussion}

Oyster rafts can create habitats for attached organisms. Small bivalves attached to the oyster rafts can be the food sources for mobile fish (especially for finfish), and the area where the oysters are cultured appears to serve as feeding grounds and nurseries for several fish species [9] Our results showed that the black seabream, pufferfish, and black scrapers were swimming under, and around oyster culture rafts. Oyster culture rafts likely act as feeding grounds by supplying food to these fish species. As reported by [14] six out of seven monitored black seabreams were observed in the oyster rafts for 55 successive days in the total observation period of 65 days by applying their tracing devices in the same location. Saito et al. [15] reported blue mussels found in the gut content of black seabream in Hiroshima Bay, indicating that black seabreams actively fed on the animals attached to the rafts. In the southwest part of Iligan Bay (Philippines), [16] reported that bivalve juveniles made up $16 \%$ of the gut content of commercially important fish species in the coral reef area. A similar scenario to the results above could also occur in $\mathrm{nHB}$, where fish were observed to be swimming actively in, and beneath the oyster rafts.

We estimated that the total fish biomass swimming in and around the oyster rafts was $333 \mathrm{~g} \mathrm{FW} \mathrm{m}^{-3}$ in Hiroshima Bay. [17] Reported that fish biomass increasing during their observation using the numerical model in Hiroshima Bay. Using an underwater visual census (UVC), [18] estimated the fish biomass on the natural oyster reefs in Western Australia to be $7.8 \mathrm{~kg}$ $\mathrm{km}^{-2}$. [19] Reported a fish biomass of $1,000 \mathrm{~kg} \mathrm{ha}^{-1}$ at a coral reef area in the Indian Ocean using the same method. Even though the fish biomass was lower in the $\mathrm{nHB}$ than in the other reports, this is most likely because of the existing differences in many of the influencing factors, such as water quality, food availability, and fishing pressure. However, it is certain the oyster culture contributes to fish abundance by providing a food source through small bivalves and other animals that are attached to the oyster rafts

\section{Conclusions}

Oyster culture rafts in Hiroshima Bay function like "artificial hanging reefs". Oysters can improve water quality by filtering suspended particles and provide a 
nurturing environment for small living organisms that serve as food sources for fish species with economic value. However, large-scale oyster culture could adversely affect the sediment quality owing to deposition of feces and pseudo feces. Evaluating the ecosystem service values - both positive and negativemay lead us to a better management strategy for the coastal ecosystem. Their existence in Hiroshima Bay is important, not only for harvesting oysters, but also for benefiting ecosystem services.

\section{Acknowledgments}

The first author thanks the Indonesian Endowment Fund for Education (LPDP) for providing financial support for their doctoral scholarship. This study was carried out with financial support from Hiroshima University, while the Hiroshima Fisheries Promotion Center provided the vessel and helped with field observations.

\section{References}

1. Newell, R. I. 2004. Ecosystem influences of natural and cultivated populations of suspensionfeeding bivalve molluscs: A review. Journal of Shellfish Research 23: 51-62.

2. Burkholder, J. M., S. E. Shumway. 2011. Bivalve shellfish aquauculture and eutrophication. In Shellfish aquaculture and the environment, ed. S.E. Shumway. Oxford, UK: Wiley-Blackwell.

3. Songsangjinda, P., O, Matsuda., T. Yamamoto, N. Rajendran, and H. Maeda. 1999. Application of water quality data to estimate the cultured oyster biomass in Hiroshima Bay: estimation of the cultured oyster biomass. Fisheries Science 65, 673-678.

4. Olivier, A. V., L. Jones, L. Vay, M. Christie, J. Wilson, and S. K. Malham. 2018. A global review of ecosystem services provided by bivalve aquaculture. Reviews in Aquaculture 12: 3-25.

5. Ministry of Agriculture, Forestry, and Fisheries of Japan (MAFF). 2015. Annual Report on Aquaculture in Japan. http://nria.fra.affrc.go.jp/ujnr/PDF/2015AnnualRe port_j.pdf. Accessed 13 November 2019.

6. Japan External Trade Organization (JETRO). 2010. Global Hiroshima specialties. https://www.jetro.go.jp/ext_images/jetro/japan/hir oshima/food/pdf/pamphlet_en_02.pdf Accessed 8 November 2019.

7. Coen, L. D., R. D. Brumbaugh, D. Bushek, R. Grizzle, M. W. Luckenbach, M. H. Posey, S. P., Tolley, S.G. 2007. Ecosystem services related to oyster restoration. Marine Ecology Progress Series 210:223-253.

8. Shumway, S. E. 2011. Shellfish aquaculture and the environment. Oxford, UK: Wiley-Blackwell.

9. Matsuda, O., P. Songsanjinda, T. Yamamoto, and N. Rajendran. 2000. Oyster culture as a biofilter, nutrient recycler and biohabitat: new perspective for sustainable environmental and resources management. Joint Conference of the 4th International Conference on the Mediterranean Coastal Environmental (MEDCOAST) and the 4th International Conference on the Environmental Management of Enclosed Coastal Seas (EMECS), pp. 13-15.

10. Dame, R. F., R. G. Zingmark, and E. Haskin. 1984. Oyster reefs as processors of estuarine materials. Journal of Experimental Marine Biology and Ecology 83: 239-247.

11. Newell, R. I., T. R. Fisher, R. R. Holyoke, and J. C. Conrwell. 2005. Influence of Eastern oysters on nitrogen and phosphorus regeneration in Chesapeake Bay. USA In The comparative Roles of Suspension-feeders in Ecosystem, eds. R. Dame, S. Olenin. The Netherlands: Springer. pp. 93-120.

12. Hirata, Y., and S, Aashige. 2004. The present situation and problems of oyster culture in Hiroshima Bay. Bulletin of Fisheries Research Agency Supplement No. 1, 5-12.

13. Yoon, H. S., Y. K. An, J. H. Hwang, H. S. Lim, W. K. Lee, K. H. Han, S. H. Lee, and S. D. Choi. 2013. Length-weight relationships for 14 fish species of the Suer River estuary in southern Korea. Journal of Applied Ichthyology 29: 468469. https://doi.org/10.1111/jai.12097

14. Tsuyuki, A., and T. Umino. (2017). Spatial movement of black seabream Acanthopagrus schlegelii around the oyster farming area in Hiroshima Bay, Japan. Fisheries Science 83: 235-244. https://doi.org/10.1007/s12562016-1058-9

15. Saito, H., Y. Nakanishi, T. Shigeta, T. Umino, K. Kawai, and H. Imabayashi. 2015. Effect of predation of fishes on oyster spats in Hiroshima Bay. Nippon Suisan Gakkaishi 74: 809-815

16. Eya, A. A., D. G. Lacuna, and A. S. Espra. 2011. Gut content analysis of selected commercially important species of coral reef fish in the Southwest part of Iligan Bay, Northern Mindano, Phillippines. Publication of the Seto Marine Biological Laboratory 41: 35-49.

17. Wahyudin, and T. Yamamoto- 2020. Modeling bottom-up and top-down controls on the low recruitment success of oyster larvae in Hiroshima Bay, Japan. Aquaculture. 529. https://doi.org/10.1016/j.aquaculture.2020.735564

18. Wilson, S. K., N. A. J. Graham, T. H. Holmes, M. A. MacNeil, and N. M. Ryan. 2018. Visual versus video methods for estimating reef fish biomass. Ecological Indicators 85: 146-152. https://doi.org/10.1016/j.ecolind.2017.10.038

19. McClanahan, T. R., J. M. Maina, N. A. J. Graham, and K. R. Jones. 2016. Modeling reef fish biomass, recovery potential, and management priorities in the Western Indian Ocean. PloS ONE 11(5): e0154585. 